\title{
Studies on the impact of smoking on the biological functions of residents of District, Multan, Pakistan
}

Khaliq Dad ${ }^{1}$, Muhammad Nawaz $^{2 *}$, Muhammad Ibrahim $^{3}$, Kainat Javaid $^{2}$, Asma Shaheen ${ }^{2}$, Rumsha Hassan ${ }^{2}$ and Shahzadi Saima ${ }^{4}$

1. Government Degree Boys College, Shah Sadder Din, D.G.Khan, Pakistan

2. Department of Environmental Sciences, Bahauddin Zakariya University, Multan, Pakistan

3. Department of Biochemistry, Bahauddin Zakariya University, Multan, Pakistan

4. Insitute of Pure \& Applied Biology, Bahauddin Zakariya University, Multan, Pakistan

*Corresponding author's email: mnawaz@bzu.edu.pk

Citation

Khaliq Dad, Muhammad Nawaz, Muhammad Ibrahim, Kainat Javaid, Asma Shaheen, Rumsha Hassan and Shahzadi Saima. Studies on the impact of smoking on the biological functions of residents of District, Multan, Pakistan. Pure and Applied Biology. Vol. 11, Issue 1, pp100-108. http://dx.doi.org/10.19045/bspab.2022.110011

\begin{tabular}{llll}
\hline \hline Received: 16/02/2021 & Revised: 28/04/2021 & Accepted: 02/05/2021 & Online First: 17/05/2021 \\
\hline
\end{tabular}

\section{Abstract}

The impacts of smoking on the biological functions of human body was studied in district Multan's habitants. In this study, the impacts of cigarette smoking on total blood count, lipid profile, and liver functioning were investigated, and in this regard, blood samples of selected people having age limits above and below 30 years, including both male \& female, were taken. Blood samples of selected population were analyzed with the help of Nishter Hospital's Physiological Laboratory, Multan. The results were expressed as percentages and Mean \pm S.E.M (standard error mean). Results showed that cigarette smoking has significant harmful impacts on the smoker's hematological parameters, lipid profile and liver functioning. It was also seen that smoking increased the level of cholesterol, triglycerides, and low-density lipoprotein (LDL) cholesterol in both male and female smokers. At the same time, results about liver functions showed that smoking decreased the level of bilirubin in both male and female smokers as compared to that of nonsmokers and also results showed that concentrations of aspartate transaminase (AST), alanine transaminase (ALT), and alkaline phosphatase (ALP) in both male and female smokers were increased as compared to that of nonsmokers. The concentration of hemoglobin, mean corpuscular hemoglobin concentration (MCHC), mean corpuscular hemoglobin $(\mathrm{MCH})$, lymphocytes and platelets in male and female smokers decreased. Overall, this study showed that smoking can have negative impacts on the biological functions of the human body with any age limit.

Keywords: Cigarette; Hematological Parameters; Lipid Profile; Liver Functioning; Smoking

\section{Introduction}

Smoking is considered as the pattern of burning and breathing of tobacco. Its antiquity can be sketched back to 5000 BC. It is known as one of the foremost public health encounters in today's era and single great inevitable deaths globally [1]. Worldwide, more or less three billion persons or more presently get affected every year from this overwhelming practice. Rendering to the WHO investigation, about 54 million deaths due to inhalation of tobacco were recorded in 2004 [2]. Despite its health dangers, tobacco use is generally common worldwide, 
particularly in emerging countries such as Pakistan. In Pakistan, cigarettes consumption was assessed at 90,000,000,000 cigarettes in year $2005[3,4]$. The tobacco industry in Pakistan is intensifying at a proportion of 5\% / year, and cigarettes of Pakistan have midst the uppermost intensities of nicotine and tar in the whole world. In count to cigarettes, the tobacco is smoldered in exceptional local methods which comprise "beedi" (tobacco bowled in desiccated leaves), "Huqqa" encompasses a mud container (chillum) comprising scorching coal over a coating of tobacco stationery to water enclosing tube with usually two pipes, one to burn and the other pipe to filter the smolder over and done with water.

The smoke of cigarette comprises more than four thousand chemical constituents that have detrimental possessions on cardiovascular functions. These comprises carbon monoxide (CO), nicotine, polycyclic aromatic hydrocarbons, oxidative gases, butadiene, carbonyls, carbon disulfide, minerals, and benzene [5]. The smoke of cigarettes produces numerous constituents together in the extracellular and cellular partitions, fluctuating from particulate substance to liquid solutes and steamy extracts. Several of these causes are recognized to be cancer-causing and poisonous to the cells of the human body on the other hand, nicotine and tar have presented to be immune-suppressive by disturbing the essential immune reaction of the consumer and enhancing the vulnerability to various infections [6]. Consuming cigarettes is accompanying by adversative human health possessions. Numerous technical studies have explored the relationship between the smoking of cigarettes and cancer [7]. In addition to cancer, cardiovascular illnesses and prolonged disruptive pulmonary ailment carry on to be the foremost health complications connected with smoking of cigarette [8].

Numerous substances amongst thousands that occur within the smoke of tobacco yield injurious and poisonous possessions on health [9]. Nicotine, including many other harmful constituents from tobacco smoke, is absorbed through the lungs into the bloodstream, and the smoke of tobacco is dispersed all over the body [10]. Smoking cigarettes is also connected with a supplementary atherogenic profile of lipid. It intensifies the concentration of serum total Cholesterol, low-density lipoprotein-Cholesterol triglycerides (LDL Cholesterol triglycerides), very low density lipoprotein-Cholesterol (VLDL- Cholesterol) and reduces the concentration of better Cholesterol, i.e., high density lipoproteinCholesterol (HDL- Cholesterol). Consequently, cigarette smoking is a foremost threat feature for coronary artery disease and atherosclerosis [11]. Cancer of the liver is the 5 th greatest general cancer in males globally, and more than $85 \%$ of liver cancers happen in unindustrialized nations. Over the previous rare periods, a total of risk dynamics for cancer of the liver have been recognized, containing hepatitis $\mathrm{C}$ virus ( $\mathrm{HCV})$, hepatitis $\mathrm{B}$ virus (HBV), alcohol drinking, aflatoxin, tobacco smoking, diabetes, and obesity [12]. Smoking tobacco is the utmost significant risk element related to prolonged emphysema and bronchitis. Parental smoking is known to intensify respiratory disease in offspring. Motherly smoking has been prominent reason for pediatric deaths of humans from stumpy birth rate, little gestation period, respiratory suffering syndrome, and unexpected newborn death disorder. Numerous health-related related complications, physiological and hematological variations are understood in humans because of smoking. Campaigns to notify the people of these risks joined with cigarette smoking regulation regulating the age of contact and smoking of cigarettes in community places, have led to an overall reduction in smoking cigarettes occurrence amongst all groups of ages [13].

The purpose of this article is to deliver a complete description of the effects of smoking on the biological functions of the residents of district Multan. The smoking rate is high in the selected district, and the residents are less aware of the effects of smoking on the body's biological functions. This is basically the major motivation for conducting the research 
on the selected topic. Most of the previous investigations covered the area of cancer. Due to this type of research's paucity, the researchers selected this topic to provide the complete description of the effects of smoking on the biological function.

\section{Materials and Methods}

\section{Locale of the study}

This study is accompanied in District Multan during December 2019 and March 2020 to estimate the significant impacts of smoking on the liver functions, lipid profile, and $\mathrm{CBC}$ to consider the interactive link with the most important demographic factors. This study comprises 250 subjects that included males $(n=125)$ and females $(n=125)$ aged, categorized in groups below 30 and above 30, were classified into two groups Smokers and Nonsmokers each test. The $5 \mathrm{ml}$ of venous blood was collected using venipuncture from all the participants. Blood samples collected were sent to the physiological laboratory of the Nishter Hospital, Multan, for evaluation. The selected parameters were analyzed using various authentic instruments including Shem100 chemistry analyzer, Cobasintega 400+ Roche and Hematology analyzer. These instruments provided measurements regarding the selected parameters including blood count, lipid profile and liver functioning of the smokers and nonsmokers. The obtained measurements were analyzed using Minitab software (version 13) and by applying One Way ANOVA. One Way ANOVA gave pvalue which was compared with the level of significance considered as 0.05 . The results were expressed as percentages and Mean \pm S.E.M (standard error mean). This distinction between mean values was evaluated through chi-square. The $\mathrm{P}$-value of $<0.05$ was considered to be statistically significant.

\section{Results and Discussion}

\section{Impact of smoking on the leukocytes of} residents of Multan district

The (Table 1) shows the effect of cigarette smoking on the leukocytes of residents of Multan district. Cigarette smoking casually affects the total number of leucocytes in the body of smokers. Prolonged tissue damage may be a potential mechanism for the amplified total count of leukocytes in smokers [14]. To determine the effects of smoking, research was conducted in which it was observed that total numbers of leucocytes were more than in people of age above thirty than the people of age below thirty, and this number is more in males than in females. These leucocytes defend the body of a person against unwanted reactions occurring in the body. A study regarding the effect of cigarette smoking on the white blood cells of smokers was conducted by [15]. Experimental results showed that numbers of leucocytes in both male and female smokers of age below thirty were increased compared to nonsmokers to defend the body against the harmful effects of smoking. While on the other hand, total number of leukocytes in both male and female smokers of age above thirty were decreased compared to nonsmokers. So, the ability to defend the body against the negative impacts of smoking automatically reduced. Hence, it was observed that age factor matters a lot in the phenomenon of smoking. The same types of results were also supported by [16]. The data were analyzed by using MS Excel and by applying One Way ANOVA. The obtained pvalue was 0.99 which is greater than the value of level of significance which is 0.05 . This basically shows that cigarette smoking has not same effects on the blood count of humans of various age factors. There is a difference between the blood chemistry of smokers and nonsmokers.

\section{Impact of smoking on RBCs, HCT, MCV and neutrophils of residents of Multan district}

The (Table 1) shows that smoking basically caused increase in red blood cells (RBCs), hematocrit (HCT), mean corpuscular volume (MCV) and neutrophils in the body of smokers. Results of the experiment showed that number of red blood cells, hematocrit (HCT), mean corpuscular volume (MCV) and neutrophils in both male and female smokers of age below and above thirty were increased as compare to nonsmokers. It was found in the study conducted by [17] that the increase in 
the number of red blood cells (RBCs) produce detrimental effects in the body of human beings. Red blood cell (RBC) membrane lipids are rich in poly-unsaturated fatty acids; therefore, the oxidative effects of oxygen on RBC membranes are greater than on other tissues. Moreover, red blood cells (RBCs) contain hemoglobin, which is one of the most potent catalysts of lipid peroxidation. The incursion of the membrane of red blood cells (RBC) by peroxidants present in cigarette, which happens with hemoglobin opathies, radioactive particle emission, the intake of oxidative drugs, enhanced intensities of specific metals and the reduced functioning of antioxidant structures, can cause red blood cells (RBC) hemolysis [18]. Observations regarding these parameters of total blood count revealed that smoking produced harmful long term effects in the body of smokers.

Same research was also conducted by [19] in which they studied the effect of tobacco smoking in cigarette form on human health. Mentioned parameters were studied in their research in which they observed the increase in number of these parameters. The increase in number of these parameters badly affected the functioning of the body of smokers. The data were analyzed by using MS Excel and by applying One Way ANOVA. The obtained pvalue was 0.99 which is greater than the value of level of significance which is 0.05 . This basically shows that cigarette smoking has not same effects on the blood count of humans of various age factors.

Impact of smoking on the haematological factors of residents of Multan district

The (Table 1) shows the impact of smoking on various hematological parameters of smokers. Constant smoking of cigarette has severe adversative special effects on haematological factors (e.g., hemoglobin, mean corpuscular volume, mean corpuscular hemoglobin concentration, lymphocytes, platelets and mixed) and these variations might be related with a bigger risk for emerging atherosclerosis, chronic obstructive pulmonary disease, polycythemia vera and/or cardiovascular diseases [20]. Observational studies on hemoglobin, mean corpuscular hemoglobin concentration (MCHC), mean corpuscular hemoglobin (MCH), lymphocytes, mixed and platelets exhibited that concentration of these parameters of total blood count decreased in smokers compared to nonsmokers. The concentration of hemoglobin, mean corpuscular hemoglobin concentration (MCHC), mean corpuscular hemoglobin $(\mathrm{MCH})$, lymphocytes, mixed and platelets in both male and female smokers of age below and above thirty was decreased when compared to the nonsmokers of same age and gender. Same types of results were also exhibited in studies conducted by [14, 21]. The data were analyzed by using MS Excel and by applying One Way ANOVA. The obtained p-value was 0.99 which is greater than the value of level of significance which is 0.05 . This basically shows that cigarette smoking has not same effects on the blood count of humans of various age factors.

Impact of smoking on the lipid profile of residents of Multan district

The (Table 2) shows the measurements regarding the impacts of smoking on the selected samples' lipid profiles. Smoking basically produces significant harmful effects on the lipid profile of the consumer. It badly disturbs the overall profile of lipids in the body of the smoker. The intensity of smoking also has been related to minor, statistically significant rises in low-density lipoprotein cholesterol (LDL-C) and reductions in highdensity lipoprotein cholesterol HDL-C [22]. The experiment results demonstrated that smoking increased the value of cholesterol, triglycerides, and low-density lipoprotein cholesterol (LDL-cholesterol) in both male and female smokers of age below and above thirty. The concentration of these selected indices usually more in males than in females. The level of these indices increases with an increase in the consumption of cigarette smoking. On the other side, cigarette smoking decreased the value of high-density lipoprotein cholesterol (HDL-cholesterol) in the body of smokers. The high-density lipoprotein cholesterol (HDL-cholesterol) 
level decreased in both male and female smokers of age below and above thirty due to smoking. A similar type of research was also conducted by $[9,10]$ in which they also observed that smoking significantly increased the value of cholesterol, triglycerides, and low-density lipoprotein cholesterol (LDLcholesterol) in smokers while decreased the value of high-density lipoprotein cholesterol (HDL-cholesterol) in the body of smokers as compared to nonsmokers which produce considerable harmful effects in smokers and disturbs the overall profile of lipids. The data were analyzed by using MS Excel and by applying One Way ANOVA. The obtained pvalue was 0.63 which is greater than the value of level of significance which is 0.05 . This basically shows that cigarette smoking has not same effects on the lipid profile of humans of various age factors.

Impact of smoking on the liver functioning of residents of Multan district

The (Table 3) demonstrates the impacts of smoking on the liver functioning of the selected samples. The conducted research showed that cigarette smoking also had significant dangerous effects on the liver functioning of smokers. Smoking is known as communal deprived living behavior in everyday life. It can destruct the antioxidant structure. Even though smoking can intensify the threat for liver fibrosis and cirrhosis in affected persons with long-lasting hepatitis B infection [23]. Experimental results explained that smoking decreased bilirubin's value in both male and female smokers of age below and above thirty compared to nonsmokers. On the other side, cigarette smoking increased the value of aspartate transaminase (AST), alanine transaminase (ALT) and alkaline phosphatase (ALP) in both male and female smokers of age below and above thirty compared to nonsmokers. The increase in aspartate transaminase (AST) level, alanine transaminase (ALT) and alkaline phosphatase (ALP) badly disturbed the functioning of the liver of smokers. A similar type of study was also conducted by $[24,25]$ in which they demonstrated the increase in the level of aspartate transaminase (AST), alanine transaminase (ALT) and alkaline phosphatase (ALP) and decrease in the level of bilirubin of smokers compared to nonsmokers or the control group. The increased level of aspartate transaminase (AST), alanine transaminase (ALT) and alkaline phosphatase (ALP) disturbed the functioning of the liver of smokers. The data were analyzed by using MS Excel and by applying One Way ANOVA. The obtained p-value was 0.99 which is greater than the value of level of significance which is 0.05 . This basically shows that cigarette smoking has not same effects on the liver functioning of humans of various age factor. 
Dad et al.

Table 1. Impact of smoking on blood count of Multan district residents

\begin{tabular}{|c|c|c|c|c|c|c|c|c|c|c|}
\hline $\begin{array}{l}\text { Complete Blood } \\
\text { Count (CBC'S) }\end{array}$ & $\begin{array}{c}\text { Normal range in } \\
\text { humans } \\
\text { Males/Females }\end{array}$ & $\begin{array}{c}\text { Female } \\
\text { Smoker } \\
\text { AGE }<30 \\
\end{array}$ & $\begin{array}{c}\text { Female } \\
\text { Nonsmoker } \\
\text { Age }<30 \\
\end{array}$ & $\begin{array}{c}\text { Male } \\
\text { Smoker } \\
\text { Age }<30 \\
\end{array}$ & $\begin{array}{c}\text { Male } \\
\text { Nonsmoker } \\
\text { AGE }<30 \\
\end{array}$ & $\begin{array}{l}\text { Female } \\
\text { Smoker } \\
\text { Age> } 30\end{array}$ & $\begin{array}{c}\text { Female } \\
\text { Nonsmoker } \\
\text { Age }>\mathbf{3 0} \\
\end{array}$ & $\begin{array}{c}\text { Male } \\
\text { Smoker } \\
\text { Age }>30 \\
\end{array}$ & $\begin{array}{c}\text { Male } \\
\text { Nonsmoker } \\
\text { Age }>\mathbf{3 0} \\
\end{array}$ & p-value \\
\hline $\begin{array}{c}\text { TLC/WBC Count } \\
\left(\mathrm{X} 103 \mathrm{~cm}^{3}\right)\end{array}$ & $4-1110^{9} / \mathrm{L}$ & $9.9 \pm 1.2$ & $6 \pm 1.9$ & $9.98 \pm 1.3$ & $9.34 \pm 1.8$ & $8.7 \pm 1.1$ & $10 \pm 1.38$ & $8.5 \pm 0.9$ & $10.8 \pm 1.3$ & 0.99 \\
\hline $\begin{array}{l}\text { RBC Count } \\
\left(\mathrm{X} 106 / \mathrm{mm}^{3}\right)\end{array}$ & $\begin{array}{c}4.5-6.5 / 3.8-5.8 \\
10^{12} / \mathrm{L}\end{array}$ & $5.7 \pm 0.6$ & $4.98 \pm 0.93$ & $5.8 \pm 0.6$ & $4.09 \pm 0.93$ & $4.27 \pm 0.21$ & $5.10 \pm 0.7$ & $6.32 \pm .06$ & $4.9 \pm 12$ & 0.99 \\
\hline $\begin{array}{l}\text { Hemoglobin } \\
\text { (gm/dl })\end{array}$ & $\begin{array}{c}130-180 / 115-165 \\
\mathrm{~g} / \mathrm{L}\end{array}$ & $9.4 \pm 0.4$ & $11.5 \pm 0.7$ & $14.1 \pm 1.2$ & $16.1 \pm 1.7$ & $10.07 \pm 0.7$ & $12 \pm 0.6$ & $13.6 \pm 2.3$ & $16.1 \pm 1.3$ & 0.99 \\
\hline HCT \% & $41-50 \% / 36-44 \%$ & $48 \pm 0.60$ & $44.28 \pm 0.45$ & $49.8 \pm 3.7$ & $47.87 \pm 0.49$ & $44.05 \pm 0.48$ & $45.0 \pm 0.85$ & $47.9 \pm 0.49$ & $45.0 \pm 0.85$ & 0.99 \\
\hline $\operatorname{MCV}\left(\mu \mathrm{m}^{3}\right)$ & $80-100 \mathrm{fl}$ & $88.64 \pm 0.8$ & $87.18 \pm 0.85$ & $89.6 \pm 2.4$ & $88.7 \pm 1.9$ & $92.4 \pm 10.7$ & $88.2 \pm 5.5$ & $88.5 \pm 1.0$ & $88.2 \pm 5.8$ & 0.99 \\
\hline MCHC (\%) & $320-360 \mathrm{~g} / \mathrm{L}$ & $31.4 \pm 1.0$ & $34.5 \pm 2.4$ & $31.9 \pm 1.5$ & $35.4 \pm 1.5$ & $27.5 \pm 2.6$ & $36.1 \pm 1.4$ & $31.8 \pm 2.1$ & $36.1 \pm 1.4$ & 0.99 \\
\hline MCH (pg) & $27-32 \mathrm{pg}$ & $25.3 \pm 1.1$ & $32.4 \pm 1.5$ & $26.3 \pm 1.2$ & $32.8 \pm 1.5$ & $24.7 \pm 3.8$ & $31.9 \pm 2.5$ & $29 \pm 2$ & $32 \pm 2.7$ & 0.99 \\
\hline Neutrophils (\%) & $2.0-7.510^{9} / \mathrm{L}$ & $70.41 \pm 0.1$ & $61.2 \pm 14.3$ & $74 \pm 10.7$ & $63.1 \pm 15.3$ & $71.5 \pm 8.8$ & $66 \pm 12$ & $73.7 \pm 7.3$ & $66 \pm 12.6$ & 0.99 \\
\hline Lymphocytes (\%) & $1.5-4.510^{9} / \mathrm{L}$ & $39.9 \pm 1.7$ & $42.1 \pm 6.7$ & $39.9 \pm 1.7$ & $40 \pm 6.9$ & $22 \pm 9$ & $28.1 \pm 4.8$ & $20.8 \pm 7.1$ & $38.6 \pm 3.8$ & 0.99 \\
\hline Mixed (\%) & $1.2-5.310^{9} / \mathrm{L}$ & $5.68 \pm 1.6$ & $7 \pm 2.6$ & $4.9 \pm 1.7$ & $7 \pm 2.8$ & $5 \pm 2.52$ & $5.2 \pm 1.4$ & $5.1 \pm 2.6$ & $5.2 \pm 1.5$ & 0.99 \\
\hline $\begin{array}{c}\text { Platelets } \\
(\text { millions } / \mathbf{m m})\end{array}$ & $150-45010^{9} / \mathrm{L}$ & $149 \pm 27$ & $329 \pm 73$ & $212 \pm 32$ & $345 \pm 39$ & $209 \pm 82$ & $334 \pm 34$ & $240 \pm 117$ & $335 \pm 37$ & 0.99 \\
\hline
\end{tabular}

$\mathrm{P}$-value $=0.99$, Level of significance $=0.05$

Table 2. Impact of smoking on lipid profile of residents of district Multan

\begin{tabular}{|c|c|c|c|c|c|c|c|c|c|c|}
\hline $\begin{array}{c}\text { Lipid Profile } \\
\text { Test }\end{array}$ & $\begin{array}{c}\text { Normal range } \\
\text { in humans } \\
\text { Males/Females }\end{array}$ & $\begin{array}{c}\text { Female } \\
\text { Smoker } \\
\text { AGE }<30 \\
\end{array}$ & $\begin{array}{c}\text { Female } \\
\text { Nonsmoker } \\
\text { Age }<30 \\
\end{array}$ & $\begin{array}{c}\text { Male } \\
\text { Smoker } \\
\text { Age }<30 \\
\end{array}$ & $\begin{array}{c}\text { Male } \\
\text { Nonsmoker } \\
\text { AGE }<30 \\
\end{array}$ & $\begin{array}{l}\text { Female } \\
\text { Smoker } \\
\text { Age> } 30\end{array}$ & $\begin{array}{c}\text { Female } \\
\text { Nonsmoker } \\
\text { Age }>\text { 30 } \\
\end{array}$ & $\begin{array}{c}\text { Male } \\
\text { Smoker } \\
\text { Age> 30 } \\
\end{array}$ & $\begin{array}{c}\text { Male } \\
\text { Nonsmoker } \\
\text { Age }>\mathbf{3 0} \\
\end{array}$ & p-value \\
\hline Cholesterol & $125-200 \mathrm{mg} / \mathrm{Dl}$ & $174.6 \pm 3.23$ & $146.3 \pm 3.14$ & $182.7 \pm 3.58$ & $148.84 \pm 3.37$ & $265 \pm 4.97$ & $211.69 \pm 3.4$ & $254.92 \pm 4.6$ & $203.6 \pm 3.81$ & 0.63 \\
\hline Triglycerides & $>150 \mathrm{mg} / \mathrm{Dl}$ & $170.89 \pm 3.48$ & $101.4 \pm 2.79$ & $175.5 \pm 3.7$ & $103.4 \pm 3.43$ & $372.56 \pm 3.48$ & $262.84 \pm 3.18$ & $355.6 \pm 3.9$ & $289.07 \pm 3.7$ & 0.63 \\
\hline $\begin{array}{c}\text { LDL } \\
\text { Cholesterol } \\
(\mathrm{mg} / \mathrm{dL}) \\
\end{array}$ & $>100 \mathrm{mg} / \mathrm{dL}$ & $128.43 \pm 2.98$ & $100.7 \pm 2.45$ & $124.4 \pm 2.2$ & $96.15 \pm 3.35$ & $149.37 \pm 3.18$ & $128.59 \pm 3.67$ & $147.8 \pm 3.58$ & $132.8 \pm 3.3$ & 0.63 \\
\hline $\begin{array}{c}\text { HDL } \\
\text { Cholesterol } \\
(\mathrm{mg} / \mathrm{dL}) \\
\end{array}$ & $40 / 50 \mathrm{mg} / \mathrm{dL}$ & $32.78 \pm 1.23$ & $45.6 \pm 1.56$ & $34.15 \pm 1.48$ & $47.07 \pm 1.94$ & $29.67 \pm 2.41$ & $50.4 \pm 1.37$ & $32.3 \pm 2.03$ & $47.2 \pm 2.01$ & 0.63 \\
\hline
\end{tabular}

$\mathrm{P}$-value $=0.63$, Level of significance $=0.05$ 
Table 3. Impact of smoking on liver functioning of residents of district Multan

\begin{tabular}{|c|c|c|c|c|c|c|c|c|c|c|}
\hline $\begin{array}{c}\text { Liver } \\
\text { Functioning } \\
\text { Test (LFT) }\end{array}$ & $\begin{array}{c}\text { Normal range } \\
\text { in humans } \\
\text { Males/Females }\end{array}$ & $\begin{array}{c}\text { Female } \\
\text { SMOKER } \\
\text { AGE }<30\end{array}$ & $\begin{array}{c}\text { Female } \\
\text { Nonsmoker } \\
\text { Age }<30\end{array}$ & $\begin{array}{c}\text { Male } \\
\text { Smoker } \\
\text { Age }<30\end{array}$ & $\begin{array}{c}\text { Male } \\
\text { Nonsmoker } \\
\text { AGE }<30\end{array}$ & $\begin{array}{l}\text { Female } \\
\text { Smoker } \\
\text { Age> } 30\end{array}$ & $\begin{array}{c}\text { Female } \\
\text { Nonsmoker } \\
\text { Age }>\mathbf{3 0}\end{array}$ & $\begin{array}{c}\text { Male } \\
\text { Smoker } \\
\text { Age }>30\end{array}$ & $\begin{array}{c}\text { Male } \\
\text { Nonsmoker } \\
\text { Age }>\mathbf{3 0}\end{array}$ & $\begin{array}{c}\text { p- } \\
\text { value }\end{array}$ \\
\hline $\begin{array}{c}\text { Total } \\
\text { bilirubin }\end{array}$ & $1.2 \mathrm{mg} / \mathrm{dL}$ & $0.54 \pm 0.26$ & $0.6 \pm 0.3$ & $0.44 \pm 0.26$ & $0.6 \pm 0.21$ & $0.9 \pm 1.44$ & $0.53 \pm 0.21$ & $0.7 \pm 0.3$ & $0.4 \pm 0.1$ & 0.99 \\
\hline AST & $\begin{array}{c}22.9 \pm 4.7 / 21.6 \\
\pm 4.0 \mathrm{IU} / \mathrm{L}\end{array}$ & $66.05 \pm 46.6$ & $26.5 \pm 5.98$ & $45.3 \pm 21.4$ & $29.4 \pm 10.0$ & $36.1 \pm 26.0$ & $23.1 \pm 18.22$ & $37.9 \pm 38$ & $40.0 \pm 36$ & 0.99 \\
\hline ALT & $\begin{array}{c}16.9 \pm 5.9 / 16.6 \\
\pm 5.5 \mathrm{IU} / \mathrm{L}\end{array}$ & $85.5 \pm 140$ & $25.3 \pm 76.4$ & $45.9 \pm 34.5$ & $30.7 \pm 13.1$ & $41.0 \pm 20.3$ & $24.1 \pm 8.22$ & $40.9 \pm 20.5$ & $39.7 \pm 36.3$ & 0.99 \\
\hline $\begin{array}{c}\text { Alkaline } \\
\text { phosphatase }\end{array}$ & 20-140 IU/L & $149.3 \pm 64.70$ & $180 \pm 32.5$ & $158 \pm 46.3$ & $134 \pm 47.36$ & $198 \pm 158.9$ & $137.2 \pm 150.0$ & $169 \pm 74.2$ & $159 \pm 69.8$ & 0.99 \\
\hline
\end{tabular}

$\mathrm{P}$-value $=0.99$, Level of significance $=0.05$ 


\section{Conclusion}

The present study's outcomes suggested that smoking is probably related to be the fundamental cause for the alterations in total blood count, lipid profile, and liver functioning. Causing irregularity in blood count, lipid profile, and liver functioning in persons who smoked is considerable. This could significantly raise if it is for the extended era of time and age of smoker matters a lot. Additional researches are required to associate blood count, lipid profile, and liver functioning with the gender and age at which smoking is initiated.

\section{Authors' contributions}

Conceived and designed the experiments: $\mathrm{K}$ Dad, Performed the experiments: M Ibrahim \& K Javaid, Analyzed the data: R Hassan \& A Shaheen, Contributed materials/ analysis/ tools: S Saima, Wrote the paper: M Nawaz.

\section{References}

1. Shah N \& Siddiqui S (2015). An overview of smoking practices in Pakistan. Pak $J$ of Med Sci 31(2): 467.

2. Hamad AWR, Khaled N, Al-Daline SM \& Al-Ani F (2015). Effect of cigarette smoking on serum and saliva liver enzymes function. European $J$ of Biomed and Pharma Sci 2(1): 107-120.

3. Nizami S, Sobani ZA, Raza E, Baloch NUA \& Khan J (2011). Causes of smoking in Pakistan: an analysis of social factors. $J$ of the Pak Med Assoc 61(2): 198.

4. Alan SE (1998). Prevalence and pattern of smoking in Pakistan. Pakistan Medical Association 48: 64-65.

5. Papathanasiou, G., Mamali, A., Papafloratos, S., \&Zerva, E (2014). Effects of smoking on cardiovascular function: the role of nicotine and carbon monoxide. Health Sci J 8(2): 274.

6. Mehta H, Nazzal K \& Sadikot RT (2008). Cigarette smoking and innate immunity. Inflamm Res 57(11): 497-503.

7. Byrd DM (2004). Review of Ingredients Added To Cigarettes Phase One: The Feasibility Of Testing Ingredients Added To Cigarettes.
8. Saha SP, Bhalla DK, Whayne Jr TF \& Gairola CG (2007). Cigarette smoke and adverse health effects: An overview of research trends and future needs. The Inter $J$ of Angiol: offic Publ of the Inter College of Angiol, Inc 16(3): 77.

9. Rashan MAA, Dawood OT, Razzaq HAA \& Hassali MA (2016). The impact of cigarette smoking on lipid profile among Iraqi smokers. Inter $J$ of Collaborative Res on Internal Med \& Pub Health 8(8): 1017.

10. Hassan EE (2013). Effect of cigarette smoking on lipid profile in male at Collage of Police and Low Khartoum, Sudan. Asian $J$ of Biomed and Pharma Sci 3(26): 28.

11. Singh D (2016). Effect of cigarette smoking on serum lipid profile in male population of Udaipur (Rajasthan). Inter $J$ Clin Biochem Res 3(4): 368-370.

12. Fan JH, Wang JB, Jiang Y, Xiang W, Liang H, Wei WQ \& Boffetta P (2013). Attributable causes of liver cancer mortality and incidence in china. Asian Pac J Cancer Prev 14(12):7251-7256.

13. Harvey J \& Chadi N (2016). Preventing smoking in children and adolescents: Recommendations for practice and policy. Pediatrics and Child Health 21(4): 209-214.

14. Ahmed OA, Ameen M \& Zainadin MR (2016). Assessment of hematological parameters of young male with hookah smoking in Rania city. Mosul $J$ of Nurs 4(1): 49-55.

15. Sherke BA, Vadapalli K, Bhargava DV, Sherke AR \& Gopireddy MMR (2016). Effect of number of cigarettes smoked per day on red blood cell, lecocyte and platelet count in adult Indian male smokers-A case control study. Inter J of Med Res \& Health Sci 5(2): 13-17.

16. Bridges AB, Hill A \& Belch JJ (1993). Cigarette smoking increases white blood cell aggregation in whole blood. $J$ of the Royal Soc of Med 86(3): 139.

17. Nadia MM, Shamseldein HA \& Sara AS (2015). Effects of Cigarette and Shisha 
Smoking on Hematological Parameters: An Analytic Case-Control Stu 10: 44-51.

18. Asgary S, Naderi GH \& Ghannady A (2005). Effects of cigarette smoke, nicotine and cotinine on red blood cell hemolysis and their-SH capacity. Exper \& Clin Cardiol 10(2): 116.

19. Pedersen KM, Çolak Y, Ellervik C, Hasselbalch HC, Bojesen SE \& Nordestgaard BG (2019). Smoking and Increased White and Red Blood Cells: A Mendelian Randomization Approach in the Copenhagen General Population Study. Arteriosclerosis, Thrombosis, and Vasc Biol 39(5): 965-977.

20. Malenica M, Prnjavorac B, Bego T, Dujic T, Semiz S, Skrbo S \& Causevic A (2017). Effect of cigarette smoking on haematological parameters in healthy population. Med Archives 71(2): 132.

21. Salamzadeh J (2010). The hematologic effects of cigarette smoking in healthy men volunteers. Iranian $J$ of Pharma Res 2: 41-47.

22. Gepner AD, Piper ME, Johnson HM, Fiore MC, Baker TB \& Stein JH (2011). Effects of smoking and smoking cessation on lipids and lipoproteins: outcomes from a randomized clinical trial. Am Heart $J$ 161(1): 145-151.

23. Ou H, Fu Y, Liao W, Zheng C \& Wu X (2019). Association between smoking and liver fibrosis among patients with nonalcoholic fatty liver disease. Canadian $J$ of Gastroenterol and Hepatol.

24. Alsalhen KS \& Abdalsalam RD (2014). Effect of cigarette smoking on liver functions: a comparative study conducted among smokers and non-smokers male in El-beida City, Libya. Inter Curr Pharma J 3(7): 291-295.

25. Battah KA, Badranc DH \& Shraideh ZA (2016). Effect of Cigarette Smoking on the Structure of Hepatocytes: TEM Study. Inter J of Morphol 34(4). 